\title{
The role of nitrogen in climate change and the impacts of nitrogen-climate interactions in the United States: foreword to thematic issue
}

\author{
Emma C. Suddick • Penelope Whitney • \\ Alan R. Townsend • Eric A. Davidson
}

Received: 12 July 2012/Accepted: 13 September 2012/Published online: 28 September 2012

(C) The Author(s) 2012. This article is published with open access at Springerlink.com

\begin{abstract}
Producing food, transportation, and energy for seven billion people has led to large and widespread increases in the use of synthetic nitrogen (N) fertilizers and fossil fuel combustion, resulting in a leakage of $\mathrm{N}$ into the environment as various forms of air and water pollution. The global $\mathrm{N}$ cycle is more severely altered by human activity than the global carbon (C) cycle, and reactive $\mathrm{N}$ dynamics affect all aspects of climate change considerations, including mitigation, adaptation, and impacts. In this special issue of Biogeochemistry, we present a review of the climate-nitrogen interactions based on a technical report for the United States National Climate Assessment presented as individual papers for terrestrial and aquatic ecosystems, agriculture and human health within the US. We provide a brief overview of each of the paper's main points and conclusions is presented in this foreword summary.
\end{abstract}

E. C. Suddick $(\bowtie) \cdot$ E. A. Davidson

The Woods Hole Research Center, 149 Woods

Hole Road, Falmouth, MA 02450, USA

e-mail: esuddick@whrc.org

P. Whitney

Resource Media, 101 Montgomery St., Suite 2600,

San Francisco, CA 94104, USA

\section{A. R. Townsend}

Department of Ecology and Evolutionary Biology, University of Colorado, INSTAAR, 1560 30th St.,

Boulder, CO 80303, USA
Keywords Nitrogen - Climate change . Interactions · US

\section{Introduction}

In the last 50 years, synthetic fertilizer production, widespread cultivation of leguminous crops, and a variety of industrial processes including fossil fuel use have greatly increased the release of reactive nitrogen $(\mathrm{Nr})$ to the environment (Vitousek et al. 1997; Galloway et al. 2004, 2008). Globally, the N cycle is perhaps the most altered of the major biogeochemical cycles, with serious implications for human health, biodiversity, and air and water quality (Vitousek et al. 1997; Galloway et al. 2008; Townsend and Howarth 2010; Davidson et al. 2012). Moreover, Nr's unwanted consequences can be further aggravated by climate change, and vice versa. Reactive nitrogen moves easily through the atmosphere, from air to water and to soil and back to plants, therefore, in its numerous chemical forms, Nr plays a critical role in all aspects of climate change considerations, including mitigation, adaptation, and impacts (Davidson et al. 2012).

The collection of papers within this Biogeochemistry special issue originated from a July 2011 workshop in Fort Collins, CO, at the US Geological Survey John Wesley Powell Center for Analysis and Synthesis. The central objective of the workshop was 
to provide in-depth analysis of climate-nitrogen interactions in both terrestrial and aquatic systems for consideration by the United States National Climate Assessment (US-NCA) for the 2013 National Climate Assessment report. The papers in this special issue reflect much of the workshop input to the USNCA, and highlight some of the most important climate- $\mathrm{N}$ interactions in terrestrial, aquatic and agricultural systems, as well as those relevant to human health concerns.

\section{Mitigation}

Nitrogen cycling affects atmospheric concentrations of the three most important anthropogenic greenhouse gases in terms of total current radiative forcing: carbon dioxide $\left(\mathrm{CO}_{2}\right)$, methane $\left(\mathrm{CH}_{4}\right)$, and nitrous oxide $\left(\mathrm{N}_{2} \mathrm{O}\right)$. Therefore, mitigation of excess $\mathrm{Nr}$ would both reduce $\mathrm{N}_{2} \mathrm{O}$ emissions and affect $\mathrm{CO}_{2}$ and $\mathrm{CH}_{4}$ in complex ways (Pinder et al. this issue). These include how $\mathrm{N}$ affects $\mathrm{C}$ sequestration in forests and soils, and how atmospheric $\mathrm{CH}_{4}$ concentrations are affected by the chemistry of nitrogen oxides $\left(\mathrm{NO}_{x}\right)$ and ozone $\left(\mathrm{O}_{3}\right)$ of which $\mathrm{NO}_{x}$ is a precursor in the lower atmosphere. Several of these $\mathrm{N}$ cycling processes have contrasting effects on the atmospheric burdens of greenhouse gases, including a possible net cooling effect on the time scale of a few decades (Pinder et al. 2012). However, most evidence suggests that minimizing $\mathrm{Nr}$ release to the environment would slow the rate of climate change over the next century (Townsend et al. 2012).

\section{Adaptation}

Understanding how nitrogen cycling affects climate change is essential, especially as adaptation to climate change involves changes in energy and water use. Although considerable progress has been made in lowering nitrogen oxide $\left(\mathrm{NO}_{x}\right)$ pollution from energy, industry, and transportation sectors in the US, this progress could slow or be reversed if energy use increases to adapt to climate change, such as to provide additional energy for air conditioning or to pump and treat water.

Adaptations to increasing water scarcity, which many regions will experience with climate change, may include greater use of surface and groundwater (Gleick 2003). This will likely exacerbate problems of elevated nitrate $\left(\mathrm{NO}_{3}{ }^{-}\right)$concentrations in waters draining to rivers, lakes, groundwater and estuaries, leading to eutrophication, costly drinking water treatments (Hoagland et al. 2002), or increased incidents of nitrate-related disease (Johnson et al. 2010). In agriculture, improvements in nutrient management such as proper timing and use of fertilizer will reduce $\mathrm{N}$ releases and could also provide some adaptive protection to crops from climate variability (Bruulsema et al. 2009). Yet unpredictable weather will also make efficient nutrient management more difficult for farmers and may worsen downstream and downwind problems: drought will cause a buildup of $\mathrm{NO}_{3}{ }^{-}$in soils and estuaries, and flooding will cause fertilizer and manure that has been applied to crops to be released more rapidly downstream and into the atmosphere (Davidson et al. 2012).

Impacts

Climate change will significantly alter $\mathrm{N}$ cycling processes, which will affect both terrestrial and aquatic ecosystems, as well as human health. Higher air temperatures will complicate air quality mitigation, because larger reductions in $\mathrm{NO}_{x}$ emissions will be needed to achieve the same reductions of $\mathrm{O}_{3}$ pollution under higher temperatures (Wu et al. 2008). Such a "climate penalty" will impose challenges to avoid harmful impacts of $\mathrm{O}_{3}$ pollution on human health (Racherla and Adams 2009) and crop productivity (Mauzerall and Wang 2001). Changes in river flow, due to summer drought and extreme precipitation events, will affect the loading and processing of $\mathrm{N}$ within rivers and estuaries. Lower river flows may reduce the total flux of $\mathrm{N}$ entering coastal regions, but would also reduce rates of flushing of estuaries, whereas higher flows will accelerate loading of $\mathrm{N}$ from terrestrial to aquatic systems. In either case, more frequent blooms of harmful or nuisance algal species are possible.

In addition, rising ambient temperatures will increase ammonia $\left(\mathrm{NH}_{3}\right)$ emissions throughout all phases of manure handling and will likely result in lower $\mathrm{N}$ use efficiency in livestock production systems and greater losses of $\mathrm{Nr}$ to the environment (Rotz 2004; Montes et al. 2009; Hristov et al. 2011). Both climate change and $\mathrm{N}$ inputs from air pollution (i.e., $\mathrm{N}$ deposition) can provoke a loss of biodiversity in aquatic and terrestrial ecosystems, due to nutrient 
enrichment of native ecosystems which favors fastgrowing, often non-native species (Rao et al. 2010). Less is known about the interacting effects $\mathrm{N}$ and climate on biodiversity, but additive or synergistic effects are indicated (Porter et al. this issue). The impacts of climate- $\mathrm{N}$ interactions on carbon (C) sequestration, agricultural productivity, aquatic ecosystems and water quality, biodiversity, and air pollution are analyzed in detail in the individual papers of this special issue.

\section{Intentional versus unintentional $\mathbf{N}$ Use in the US}

Using mass-balance principals and pre-existing data on long-term trends in $\mathrm{Nr}$ creation, Houlton et al. (this issue) examine $\mathrm{Nr}$ use efficiencies within the food, fiber, energy and industrial sectors of the continental US. Estimates show that human actions in the US have increased $\mathrm{Nr}$ inputs into the environment by at least $\sim 5$ times compared to pre-industrial conditions.

- Focusing on two time points (2002 and 2007, for which all major $\mathrm{N}$ flow data were available and no major changes in $\mathrm{Nr}$ were observed), humans introduced approximately $29 \mathrm{Tg}\left(10^{12} \mathrm{~g}\right)$ of newly formed $\mathrm{Nr}$ into the US; with $24.7 \mathrm{Tg} \mathrm{N}$ intentionally occurring through the Haber-Bosch process to create $\mathrm{N}$ fertilizers and the cultivation of crops that biologically fix $\mathrm{N}$ (C-BNF). The remainder, approximately $15-20 \%$ of the total, occurs from unintentional $\mathrm{N}$ fixation derived from vehicle use, fossil fuel combustion by stationary power plants, industrial boilers, and other similar processes. This is compared to the $6.5 \mathrm{Tg} \mathrm{N}$ year ${ }^{-1} \mathrm{~N}$ fixed naturally from lightening strikes $(2 \%)$ and biological nitrogen fixation (BNF; $98 \%$ ) (SAB 2011).

- On an annual basis, about $54 \%(13.7 \mathrm{Tg} \mathrm{N})$ of $\mathrm{Nr}$ intentionally introduced into the US is converted to food, livestock feed, biofuel (energy), or industrial products. Considering only the agricultural sector, approximately $38 \%$ of agricultural $\mathrm{N}$ inputs (e.g., synthetic fertilizer and $\mathrm{N}$ fixation by leguminous crops) enter the annual food and livestock feed supply, making it the dominant sink for intentional $\mathrm{Nr}$ in the US.

- For the US an estimated $2 \%$ of intentional $\mathrm{Nr}$ escapes to the atmosphere as $\mathrm{N}_{2} \mathrm{O}$, where it contributes to climate change (Pinder et al.
2012), and $12 \%$ as $\mathrm{NO}_{x}$ and $\mathrm{NH}_{3}$ to the air where it contributes to poor air quality via tropospheric $\mathrm{O}_{3}$ and particulate matter (Muller and Mendelsohn 2007). An uncertain fraction-from 3 to $21 \%$ - of $\mathrm{Nr}$ is converted to $\mathrm{N}_{2}$, an effectively unreactive and stable form of $\mathrm{N}$ in the Earth system.

- Leaching of $\mathrm{N}$ to surface waters and groundwater has also increased substantially in the US and around the globe. Houlton et al. (this issue) estimate that approximately $13 \%(4-5 \mathrm{Tg} \mathrm{N})$ is released into the hydrosphere where it contributes to eutrophication (Diaz and Rosenberg 2008) and drinking water risks (Ward et al. 2005).

\section{Nitrogen's contribution to climate change: radiative forcing}

A direct affect on global warming occurs through emissions of $\mathrm{N}_{2} \mathrm{O}$, a greenhouse gas $\sim 300$ times more potent than $\mathrm{CO}_{2}$, with long-term warming effects because of its $>100$ year residence time in the atmosphere. Most of the increases in $\mathrm{N}_{2} \mathrm{O}$ come from fertilized agricultural soils and from livestock manure, about 0.48 million tons of $\mathrm{N}_{2} \mathrm{O}-\mathrm{N}$ year ${ }^{-1}$, which is about $80 \%$ of total anthropogenic US $\mathrm{N}_{2} \mathrm{O}$ production (the remainder derives from energy and industrial sources) (US-EPA 2011). Pinder et al. (this issue) review the climate change impact of $\mathrm{Nr}$ and $\mathrm{N}$ cycle process on radiative forcing in the US and calculate the global temperature potential (GTP) over a 20 year or 100 year time period.

- Overall, the effect of $\mathrm{N}$ cycling processes in the US on global warming is probably a modest cooling effect for a 20-year time frame, and a modest warming for a 100-year time frame. In short, combustion sources of $\mathrm{Nr}$ that are likely causing cooling are declining in the US due to enforcement of air pollution regulations for human health. In contrast, most agricultural sources of $\mathrm{Nr}$ cause long-term warming, especially $\mathrm{N}_{2} \mathrm{O}$, and these are mostly unregulated and are increasing.

- Emissions of $\mathrm{NO}_{x}$, indirectly affect radiative forcing through the effects on atmospheric concentrations of $\mathrm{CH}_{4}, \mathrm{O}_{3}$, and aerosol particulate matter (PM). These effects are complex and difficult to quantify (Rypdal et al. 2009; Penner et al. 2010; Myhre et al. 2011). However, they 
generally result in a net cooling effect on time scales of days to decades, becoming insignificant on longer time scales (Boucher et al. 2009).

- Emissions of $\mathrm{NO}_{x}$ and $\mathrm{NH}_{3}$ are chemically transformed and eventually deposited onto ecosystems via wet (e.g., rain or snow) and dry (e.g., wind) deposition. This increases the availability of $\mathrm{N}$ to ecosystems, which can affect the sources and sinks of $\mathrm{N}_{2} \mathrm{O}, \mathrm{CH}_{4}$, and $\mathrm{CO}_{2}$, with the dominant effect being enhanced sequestration of $\mathrm{C}$.

- The literature reviewed here reports a range of estimates of $20-70 \mathrm{~kg} \mathrm{C}$ sequestered per $\mathrm{kg} \mathrm{N}$ deposited onto forests, which are the dominant potential C sinks (Butterbach-Bahl et al. 2011; Thomas et al. 2010). Most of the sequestration occurs in aboveground forest biomass, with less consistency and lower rates reported for $\mathrm{C}$ sequestration in soils. The permanency of the forest biomass sink is uncertain, but data on forest product fates in the US indicate that only a small fraction of enhanced forest biomass $\mathrm{C}$ is sequestered in long-term harvest products or in unmanaged forests.

\section{Nitrogen-climate interactions and impacts}

Climate change will almost certainly increase the release of $\mathrm{Nr}$, which in turn will impact agriculture, land and aquatic ecosystems and human health. In each of these sectors, a changing climate and greater $\mathrm{Nr}$ release can then interact in a variety of ways, further complicating attempts to manage and maintain key ecosystem services.

\section{Agriculture}

Robertson et al. (this issue) review literature to understand $\mathrm{N}$ cycling and climate change- $\mathrm{N}$ interactions and the subsequent impact on agricultural systems. Climate change- $\mathrm{N}$ interactions affect agricultural productivity in part through exposure of crops to elevated $\mathrm{O}_{3}$. These interactions will also result in greater emissions of $\mathrm{Nr}$ from livestock and cropping systems. Climate change impacts including drought, heat, and higher rainfall will hinder the ability of farmers to match crop needs with appropriate fertilizer applications, causing additional $\mathrm{N}$ releases to water and air, especially if higher fertilizer rates are used to meet climate challenges on crop growth.

- Increases in temperature can lead to higher rates of precursor emissions and $\mathrm{O}_{3}$ formation. Based on large-scale experimental studies in the US (Heagle 1989; Heck 1989), higher $\mathrm{O}_{3}$ levels will decrease crop growth and yield in a variety of crops (Mills et al. 2007; Emberson et al. 2009). Model simulations of $\mathrm{O}_{3}$ used with these established concentration and yield response relationships predict larger effects for grain crops for 2000 and 2030 (Avnery et al. 2011a, b).

- Projected temperature changes will increase $\mathrm{NH}_{3}$ emissions throughout all phases of manure handling (Montes et al. 2009), likely hampering the efforts of livestock industries to improve $\mathrm{N}$ use efficiency and causing greater losses of $\mathrm{Nr}$ to the environment. These effects can lead to lower production, lower reproduction, and higher mortality (Nardone et al. 2010). As production is increased elsewhere to make up for this lost productivity, more $\mathrm{N}$ will be needed and $\mathrm{Nr}$ releases to the environment will increase. Under our current climate, heat stress is estimated to cause an annual economic loss of 1.7-2.4 billion dollars in the US livestock sector (St-Pierre et al. 2003).

- Flooding and extreme precipitation can also cause major releases of $\mathrm{Nr}$ as excess water drains from fields and through gaseous losses of $\mathrm{N}_{2} \mathrm{O}$ from wet soils. Increased $\mathrm{NO}_{3}{ }^{-}$flushed from agricultural systems due to irregular precipitation (Davidson et al. 2012) will pose greater risks to groundwater and drinking water safety.

\section{Aquatic ecosystems and resources}

The loading of $\mathrm{N}$ from watersheds and atmospheric deposition has more than doubled the flux of $\mathrm{N}$ to estuaries and coastal oceans since the industrial and agricultural revolutions (Howarth et al. 2011a; Boyer and Howarth 2008). For many US watersheds, the relative increase is far greater, sometimes exceeding an order of magnitude. A review of $\mathrm{Nr}$ inputs to various aquatic systems through literature sources and model outputs by Baron et al. (this issue), have shown that nearly all freshwaters and coastal zones in US are degraded by $\mathrm{N}$ pollution, including remote sources in alpine regions such as Rocky Mountain National Park 
in Colorado. Inputs to river systems were estimated with the USGS SPARROW model to be $4.8 \mathrm{Tg}$ $\mathrm{N}$ year $^{-1}$ in 2002 (SAB 2011; Alexander et al. 2008). North American riverine $\mathrm{N}$ export to the coastal zone, inlands and drylands was estimated at approximately 7.0 Tg N year ${ }^{-1}$ (Boyer et al. 2006). Adverse effects range from eutrophication and acidification to human health risks, biodiversity loss, and economic costs to fisheries and tourism from the increased frequency of harmful algal blooms (Bricker et al. 2007; SAB 2011).

Aquatic ecosystems are critically important to $\mathrm{N}$ processing because of their ability to transform $\mathrm{Nr}$ into unreactive $\mathrm{N}_{2}$ gas during denitrification (although some $\mathrm{N}_{2} \mathrm{O}$ is also produced). One estimate suggests one-fifth of global denitrification occurs in freshwater such as lakes and rivers (Seitzinger et al. 2006). Both hydrologic manipulation by human-made infrastructure and climate change alter the landscape connectivity and hydrologic residence times that are essential for denitrification (Howarth et al. 2011b). The effect of climate change on $\mathrm{N}$ processing in fresh and coastal waters will be felt most strongly through precipitation changes. This will speed or slow runoff, thereby influencing the rate $\mathrm{Nr}$ is added to aquatic systems and groundwater, and the average time water resides in a body of water such as a reservoir, a process that aids $\mathrm{N}$ removal. Other impacts include:

- More extreme precipitation events will flush fertilizer or manure into streams or groundwater. Freshwater bodies such as lakes will have less time to process and reduce excess $\mathrm{N}$ before it travels further downstream or is transported into the atmosphere.

- Algal blooms, which are linked to nutrient enrichment and warm waters (Heisler et al. 2008), will occur more frequently. These have been linked to human health impacts, such as swimmers itch, food poisoning, cancer, and paralysis (Johnson et al. 2010). Harmful algal blooms are responsible for massive fish kills and marine mammal kills (Morris 1999).

- Increasing numbers of studies show correlations between $\mathrm{N}$ enrichment in waters and pathogen abundance and diseases of both humans and wildlife (Johnson et al. 2010). Many mosquitoes that are carriers of diseases like malaria or West Nile Virus and other parasites associated with warm climates or seasons have increased breeding success in waters high in $\mathrm{NO}_{3}^{-}$(Johnson et al. 2010).
- American reliance on groundwater for drinking water is expected to increase under future climate change scenarios. In addition, there will likely be increases in costs for treating drinking water to avoid exposure to $\mathrm{NO}_{3}{ }^{-}$, which contributes to the formation of $\mathrm{N}$-nitroso compounds associated with cancer, diabetes, and reproductive problems such as premature birth (Ward et al. 2005). At present, approximately 1.2 million Americans use private, shallow groundwater wells in areas with estimated $\mathrm{NO}_{3}{ }^{-}$concentrations between 5 and $10 \mathrm{mg} \mathrm{L}^{-1}$, and about 0.5 million use groundwater in areas with estimated $\mathrm{NO}_{3}{ }^{-}>10 \mathrm{mg} \mathrm{L}{ }^{-1}$ (Nolan and Hitt 2006). A recent study showed that the maximum $\mathrm{NO}_{3}{ }^{-}$contaminant level of $10 \mathrm{mg} \mathrm{L}^{-1}$ was exceeded in $22 \%$ of domestic wells in agricultural areas (Dubrovsky et al. 2010). Model results also suggest that deeper groundwater supplies may be contaminated in the future as $\mathrm{NO}_{3}{ }^{-}$in shallow groundwater migrates downward and is slow to respond to changes in management (Nolan and Hitt 2006; Exner et al. 2010; Howden et al. 2010).

\section{Biodiversity}

Biodiversity loss is caused by loss of habitat, overexploitation, invasive species, climate change, and pollution, including $\mathrm{N}$ pollution (Millennium Ecosystem Assessment (MEA) 2005; Hooper et al. 2012). Porter et al. (this issue) review and show that the results from both empirical studies and modeling indicate $\mathrm{N}$ pollution coupled with climate change can drive species losses that are greater than those caused by either stressor alone; including favoring the growth of fast-growing non-native species that favor or can adapt to high levels of $\mathrm{N}$.

- For example, controlled experiments in California grassland have shown that increased $\mathrm{N}$ and $\mathrm{CO}_{2}$, separately and in combination, significantly reduced forb diversity (Zavaleta et al. 2003). In arid ecosystems of southern California, elevated $\mathrm{N}$ deposition and changing precipitation patterns have promoted the conversion of native shrub communities to communities dominated by a few species of annual non-native grasses. A change in biodiversity can also affect ecosystem function, such as increasing fire risk where fuel accumulation was previously rare (Rao et al. 2010). 
- Earlier snowmelt in high elevation sites has caused earlier starts to the growing season, increasing the exposure of some plants to killing frosts (Inouye 2008). Excess $\mathrm{N}$ deposition has been associated with greater frost sensitivity in conifer species (Perkins et al. 2000). The combination of more frequent frosts and greater plant sensitivity to those frosts can cause greater die-off of those species.

- Some estuaries, such as the New York harbor estuary, have experienced more occurrences of algal blooms and become more eutrophic. In New York, this is due to less winter snowpack in the Adirondack Mountains, which has increased the amount of time water resides in the estuary over the summer and decreases $\mathrm{N}$ flushing (Howarth et al. 1999). In addition, the St. Lawrence Estuary and Gulf of St. Lawrence have also become hypoxic in recent years, as their bottom waters now come more from the deep Atlantic water and less from the Labrador Current (Gilbert et al. 2005; Howarth et al. 2011a). Moreover, due to greater stratification, productivity in the Dead Zone area in the Gulf of Mexico has become co-limited by phosphorus $(\mathrm{P})$, causing less $\mathrm{N}$ uptake, more $\mathrm{Nr}$ loss in coastal environments, and greater transport of $\mathrm{Nr}$ to deeper waters (Sylvan et al. 2006; Donner and Scavia 2007).

Air pollution and human health

Nitrogen pollution plays an important role in air quality and the resulting impacts on human health (Peel et al. this issue). Emissions of $\mathrm{Nr}$ released into the atmosphere from agriculture, industry, and urban areas contribute to high levels of fine particulate matter $\left(\mathrm{PM}_{2.5}\right)$, ground-level $\mathrm{O}_{3}$, and $\mathrm{NO}_{x}$ in the air we breathe and can cause premature death and a variety of serious health effects (US-EPA 2006, 2008, 2009). In addition, $\mathrm{NO}_{x}$ is a key component of $\mathrm{O}_{3}$ creation in the lower atmosphere, which affects air quality for both human health and crop productivity.

- Changes in temperature and precipitation patterns are projected to both lengthen the $\mathrm{O}_{3}$ season and intensify high $\mathrm{O}_{3}$ episodes in some areas. Recent studies have provided evidence that the adverse health consequences of ambient $\mathrm{O}_{3}$ pollution increase when temperatures are higher (Jacob and Winner 2009). A longer $\mathrm{O}_{3}$ season could result in $\mathrm{O}_{3}$ exposure overlapping the spring and fall respiratory viral and asthma seasons. In addition, there is evidence that $\mathrm{O}_{3}$ and other pollutants can enhance the susceptibility to and the severity of respiratory infections and increase sensitization to allergens (Chauhan et al. 2003; Ciencewicki and Jaspers 2007; Rusznak et al. 1996).

- Other climate-related changes may increase the atmospheric release of $\mathrm{N}$-containing air pollution precursors and reactants by impacting wildfire regimes, emissions from soil, and volatile organic carbon (VOC) emissions from terrestrial ecosystems. Increases in climate-induced anthropogenic $\mathrm{NO}_{x}$ emissions are more likely during the summer, when extreme $\mathrm{O}_{3}$ events are most common and when $\mathrm{O}_{3}$ formation is most sensitive to $\mathrm{NO}_{x}$ emissions (e.g., Jacob 1999; Liao et al. 2010; Weaver et al. 2009).

- The impact of climate change on $\mathrm{PM}_{2.5}$ levels is less clear than for $\mathrm{O}_{3}$. While climate-induced severe air stagnation events can lead to increased pollutant levels, $\mathrm{PM}_{2.5}$ formation is expected to decrease in areas where rainfall is expected to increase and/or become extended. Higher temperatures will also shift the thermodynamic equilibrium away from nitric acid combining with $\mathrm{NH}_{3}$ to form the ammonium nitrate $\left(\mathrm{NH}_{4} \mathrm{NO}_{3}\right)$ aerosol, leading to lower levels of that aerosol product (Stelson and Seinfeld 1982; Dawson et al. 2007; Mahmud et al. 2010). Accordingly, the impact that climate change will have on $\mathrm{PM}_{2.5}$ will likely vary regionally.

- Vulnerability to the joint impacts of N-related air pollutants and global climate change will reflect the non-uniform distribution of human exposures (Morello-Frosch et al. 2011). Furthermore, vulnerability to the impact of both air pollution and temperature is greater in the absence of air conditioning, which has been shown to prevent or reduce infiltration of many ambient air pollutants indoors as well as to affect vulnerability to heat waves. This vulnerability has been shown to covary with socioeconomic status, education, poverty and race, social isolation, age, and preexisting diseases (e.g., diabetes; Reid et al. 2009).

- Although some components of air quality have been improving in the US and are expected to improve further as $\mathrm{NO}_{x}$ emissions decrease due to 
current control programs, in a warmer world, larger reductions in $\mathrm{NO}_{x}$ will be needed to achieve the same reductions of ozone due to the "climate penalty" (Wu et al. 2008). Air pollution may worsen even if current regulations continue to reduce $\mathrm{NO}_{x}$ emissions.

\section{Potential mitigation solutions}

Reducing N pollution can be used as a lever to avert or slow impending climate impacts. Policies aimed at improving $\mathrm{N}$ use efficiencies in agriculture and reducing emissions from transportation and energy sectors, would have multiple interacting benefits for climate mitigation and for minimizing climate change impacts on crop productivity, air and water quality, biodiversity, and human health risks (Townsend et al. 2012). To date, the greatest success has been through the Clean Air Act enforcement, which has dramatically reduced industrial and transportation $\mathrm{NO}_{x}$ emissions from smokestack and combustion sources.

In addition, the opportunities for further reductions are greatest in agricultural systems, since its use of $\mathrm{N}$ is often inefficient. Applying current practices and technologies could reduce $\mathrm{Nr}$ pollution from farm and livestock operations by 30-50\% (Robertson and Vitousek 2009; Davidson et al. 2012). They include managing fertilizer timing, optimizing fertilizer use, and implementing wetlands, wood chip trenches, cover crops, and streamside vegetation to mitigate excess $\mathrm{N}$ released into the environment. While agriculture is the major source of N pollution in the US and worldwide, there is little national awareness of the connection between agricultural activities and human health that would spur effective regulatory action. Outside of $\mathrm{N}$ pollution hotspots like the Chesapeake Bay or Gulf of Mexico, which have borne economic costs to their fisheries, there has been little political will to improve agricultural management and reduce agricultural releases. As efforts to reduce $\mathrm{N}$ pollution are not as nationally politicized as the climate debate, focusing on reducing $\mathrm{Nr}$ from agriculture, with its cobenefits for reducing human health risks, could offer promise.

Emphasizing the damage costs of $\mathrm{Nr}$ on clean air, safe drinking water and fisheries could build the public will and support for funding federal agricultural conservation programs to extensively reduce $\mathrm{N}$ releases. A recent EPA study by Compton et al. (2011) showed that the human health costs of $\mathrm{NO}_{x}$ releases are about $\$ 23$ per kilogram. Looking at coastal eutrophication, the cost of fisheries decline in the Gulf of Mexico is estimated to be $\$ 56$ per kilogram of excess $\mathrm{Nr}$ released. Most importantly, prevention costs were found to be far less than the total costs of the resulting pollution, with current efforts in Chesapeake Bay to prevent and reduce $\mathrm{N}$ loads into the Bay ranging from $\$ 8$ to $\$ 15$ per kilogram. Clearly, action is needed, as reducing $\mathrm{Nr}$ releases from all sectors will almost certainly help slow the rate of climate change over the next century.

Perturbations to both climate and the $\mathrm{N}$ cycle will cause multiple stressors to ecosystem function and human health that are likely to be additive or synergistic. Although our knowledge of those interactions is incomplete, we know a great deal about mitigation of climate change and mitigation of excess $\mathrm{N}$ in the environment. As with climate change, political and economic impediments often stand in the way of mitigating releases of excess $\mathrm{N}$ to the environment (Davidson et al. 2012). However, we demonstrate in this special issue of Biogeochemistry that policies aimed at improving national $\mathrm{N}$ use efficiencies (NUE) would: (i) benefit the US economy on the production side; (ii) reduce social damage costs; and (iii) help avoid some major climate change risks in the future.

Acknowledgments This work resulted from a workshop supported by NSF Research Coordination Network awards DEB-0443439 and DEB-1049744 and by the David and Lucille Packard Foundation. We would like to thank all the authors of each of the papers in this special issue for preparing the NCA technical report and for putting together these papers. In addition we would like to thank those who provided prior reviews and comments.

Open Access This article is distributed under the terms of the Creative Commons Attribution License which permits any use, distribution, and reproduction in any medium, provided the original author(s) and the source are credited.

\section{References}

Alexander RB, Smith RA, Schwarz GE, Boyer EW, Nolan JV, Brakebill JW (2008) Differences in phosphorus and nitrogen delivery to the gulf of Mexico from the Mississippi river basin. Environ Sci Technol 42(3):822-830. doi: 10.1021/es0716103 
Avnery S, Mauzerall DL, Liu J, Horowitz LW (2011a) Global crop yield reductions due to surface ozone exposure: 1 . Year 2000 crop production losses and economic damage. Atmos Environ 45:2284-2296

Avnery S, Mauzerall DL, Liu J, Horowitz LW (2011b) Global crop yield reductions due to surface ozone exposure: 2 . Year 2030 potential crop production losses and economic damage under two scenarios of $\mathrm{O}_{3}$ pollution. Atmos Environ 45(13):2297-2309

Baron JS, Hall EK, Nolan BT, Finlay JC, Bernhardt ES, Harrison JA, Chan F, Boyer EW (submitted) The interactive effects of human-derived nitrogen loading and climate change on aquatic ecosystems of the United States. Biogeochemistry, special issue climate-nitrogen interactions (this issue)

Boucher O, Friedlingstein P, Collins B, Shine KP (2009) The indirect global warming potential and global temperature change potential due to methane oxidation. Environ Res Lett 4(4):044007

Boyer EW, Howarth RT (2008) Nitrogen fluxes from rivers to the coastal oceans. In: Nitrogen in the marine environment, 2nd edn. Elsevier, Boston, pp 1565-1587

Boyer EW, Alexander RB, Parton WJ, Li CS, Butterbach-Bahl K, Donner SD, Skaggs RW, Del Gross SJ (2006) Modeling denitrification in terrestrial and aquatic ecosystems at regional scales. Ecol Appl 16(6):2123-2142. doi:10.1890/ 1051-0761(2006)016[2123:mditaa]2.0.co;2

Bricker S, Longstaff B, Dennison W, Jones A, Boicourt K, Wicks C, Woerner J (2007) Effects of nutrient enrichment in the nation's estuaries: a decade of change. NOAA coastal ocean program decision analysis series No. 26. National Centers for Coastal Ocean Science, Silver Spring, p 328

Bruulsema TW, Lemunyon J, Herz W (2009) Know your fertilizer rights. Crops Soils Am Soc Agron 42:13-18

Butterbach-Bahl K, Nemitz E, Zaehle S (2011) The European nitrogen assessment. Cambridge University Press, Cambridge

Chauhan AJ, Inskip HM, Linaker CH, Smith S, Schreiber J, Johnston SL, Holgate ST (2003) Personal exposure to nitrogen dioxide (NO2) and the severity of virus-induced asthma in children. Lancet 361:1939-2194

Ciencewicki J, Jaspers I (2007) Air pollution and respiratory viral infection. Inhal Toxicol 14:1135-1146

Compton JE, Harrison JA, Dennis RL, Greaver TL, Hill BH, Jordan SJ, Walker H, Campbell HV (2011) Ecosystem services altered by human changes in the nitrogen cycle: a new perspective for US decision making. Ecol Lett 14(8):804-815

Davidson EA, David MB, Galloway JN, Goodale CL, Haeuber R, Harrison JA, Howarth RW, Jaynes DB, Lowrance RR, Nolan BT et al (2012) Excess nitrogen in the U.S. environment: trends, risks, and solutions. ESA Issues Ecol 15:1-16

Dawson JP, Adams PJ, Pandis SN (2007) Sensitivity of PM2.5 to climate in the Eastern US: a modeling case study. Atmos Chem Phys 7(16):4295-4309

Diaz RJ, Rosenberg R (2008) Spreading dead zones and consequences for marine ecosystems. Science 321(5891): 926-929

Donner SD, Scavia D (2007) How climate controls the flux of nitrogen by the Mississippi River and the development of hypoxia in the Gulf of Mexico. Limnol Oceanogr 52(2): 856-861

Dubrovsky NM, Burow KR, Clark GM, Gronberg JM, Hamilton PA, Hitt KJ, Mueller DK, Munn MD, Nolan BT, Puckett LJ, et al (2010) The quality of our Nation's watersnutrients in the nation's streams and groundwater, 1992-2004. U.S. Geological Survey Circular 1350

Emberson LD, Büker P, Ashmore MR, Mills G, Jackson LS, Agrawal M, Atikuzzaman MD, Cinderby S, Engardt M, Jamir C et al (2009) A comparison of North American and Asian exposure-response data for ozone effects on crop yields. Atmos Environ 43(12):1945-1953

Exner ME, Perea-Estrada H, Spalding RF (2010) Long-term response of groundwater nitrate concentrations to management regulations in Nebraska's Central Platte Valley. Sci World J 10:286-297. doi:10.1100/tsw.2010.25

Galloway JN, Dentener FJ, Capone DG, Boyer EW, Howarth RW, Seitzinger SP, Asner GP, Cleveland CC, Green PA, Holland EA, Karl DM, Michaels AF, Porter JH, Townsend AR, Vorosmarty CJ (2004) Nitrogen cycles: past, present, and future. Biogeochemistry 70(2):153-226

Galloway JN, Townsend AR, Erisman JW, Bekunda M, Cai ZC, Freney JR, Martinelli LA, Seitzinger SP, Sutton MA (2008) Transformation of the nitrogen cycle: recent trends, questions, and potential solutions. Science 320(5878): 889-892

Gilbert D, Sundby B, Gobeil C, Mucci A, Tremblay GH (2005) A seventy-two-year record of diminishing deep-water oxygen in the St. Lawrence estuary: the northwest Atlantic connection. Limnol Oceanogr 50(5):1654-1666

Gleick PH (2003) Water use. Ann Rev Environ Resour 28: 275-314

Heagle AS (1989) Ozone and crop yield. Ann Rev Phytopathol 27(1):397-423. doi:10.1146/annurev.py.27.090189.002145

Heck WW (1989) Assessment of crop losses from air pollutants in the United States. In: Air pollution's toll on forests and crops. Yale University Press, New Haven, pp 235-315

Heisler J, Glibert PM, Burkholder JM, Anderson DM, Cochlan W, Dennison WC, Dortch Q, Gobler CJ, Heil CA, Humphries E et al (2008) Eutrophication and harmful algal blooms: a scientific consensus. Harmful Algae 8(1):3-13. doi:10.1016/j.hal.2008.08.006

Hoagland P, Anderson DM, Kaoru Y, White AW (2002) The economic effects of harmful algal blooms in the United States: estimates, assessment issues, and information needs. Estuaries 25:819-837

Hooper DU, Adair EC, Cardinale BJ, Byrnes JEK, Hungate BA, Matulich KL, Gonzalez A, Duffy JE, Gamfeldt L, O'Connor MI (2012) A global synthesis reveals biodiversity loss as a major driver of ecosystem change. Nature. doi:10.1038/nature11118

Houlton BZ, Boyer E, Finzi A, Galloway J, Leach A, Liptzin D, Melillo J, Rosenstock TS, Sobota D, Townsend AR (submitted) Intentional vs. unintentional nitrogen use in the United States: Trends, efficiency, and implications. Biogeochemistry, special issue climate-nitrogen interactions (this issue)

Howarth RW, Chan F, Marino R (1999) Do top-down and bottom-up controls interact to exclude nitrogen-fixing cyanobacteria from the plankton of estuaries: explorations with a simulation model. Biogeochemistry 46:203-231 
Howarth R, Chan F, Conley DJ, Garnier J, Doney SC, Marino R, Billen G (2011a) Coupled biogeochemical cycles: eutrophication and hypoxia in temperate estuaries and coastal marine ecosystems. Front Ecol Environ 9(1):18-26. doi: $10.1890 / 100008$

Howarth R, Swaney D, Billen G, Garnier J, Hong B, Humborg C, Johnes P, Marth CM, Marino R (2011b) Nitrogen fluxes from the landscape are controlled by net anthropogenic nitrogen inputs and by climate. Front Ecol Environ 10(1):37-43. doi:10.1890/100178

Howden NJK, Burt TP, Worrall F, Whelan MJ, Bieroza M (2010) Nitrate concentrations and fluxes in the River Thames over 140 years (1868-2008): are increases irreversible? Hydrol Process 24(18):2657-2662. doi:10.1002/ hyp. 7835

Hristov AN, Hanigan M, Cole A, Todd R, McAllister TA, Ndegwa PM, Rotz A (2011) Review: ammonia emissions from dairy farms and beef feedlots. Can J Anim Sci 91:1-35

Inouye DW (2008) Effects of climate change on phenology, frost damage, and floral abundance of montane wildflowers. Ecology 89(2):353-362. doi:10.1890/06-2128.1

Jacob DJ (1999) Introduction to atmospheric chemistry. http:// acmg.seas.harvard.edu/publications/jacobbook/index.htm.l. Princeton University Press, Princeton

Jacob DJ, Winner DA (2009) Effect of climate change on air quality. Atmos Environ 43(1):51-63. doi:10.1016/j.atmosenv. 2008.09.051

Johnson PT, Townsend AR, Cleveland CC, Glibert PM, Howarth RW, McKenzie VJ, Rejmankova E, Ward MH (2010) Linking environmental nutrient enrichment and disease emergence in humans and wildlife. Ecol Appl 20(1):16-29

Liao KJ, Tagaris E, Russell AG, Amar P, He S, Manomaiphiboon K, Woo JH (2010) Cost analysis of impacts of climate change on regional air quality. J Air Waste Manag Assoc 60:195-203. doi:10.3155/1047-3289.3160.3152.3195

Mahmud A, Hixson M, Hu J, Zhao Z, Chen SH, Kleeman MJ (2010) Climate impact on airborne particulate matter concentrations in California using seven year analysis periods. Atmos Chem Phys 10(22):11097-11114

Mauzerall DL, Wang XP (2001) Protecting agricultural crops from the effects of tropospheric ozone exposure: reconciling science and standard setting in the United States, Europe, and Asia. Annu Rev Energy Env 26:237-268

Millennium Ecosystem Assessment (MEA) (2005) Ecosystems and human well-being: biodiversity synthesis. World Resources Institute, Washington, DC

Mills G, Buse A, Gimeno B, Bermejo V, Holland M, Emberson L, Pleijel H (2007) A synthesis of AOT40-based response functions and critical levels of ozone for agricultural and horticultural crops. Atmos Environ 41(12):2630-2643. doi:10.1016/j.atmosenv.2006.11.016

Montes F, Rotz CA, Chaoui H (2009) Process modeling of ammonia volatilization from ammonium solution and manure surfaces: a review with recommended models. Trans ASABE 52(5):1707-1719

Morello-Frosch R, Zuk M, Jerrett M, Shamasunder B, Kyle AD (2011) Understanding the cumulative impacts of inequalities in environmental health: implications for policy. Health Affairs (Millwood) 5:879-887
Morris JG (1999) Harmful algal blooms: an emerging public health problem with possible links to human stress on the environment. Annu Rev Energy Env 24:367-390. doi: 10.1146/annurev.energy.24.1.367

Muller NZ, Mendelsohn R (2007) Measuring the damages of air pollution in the United States. J Environ Econ Manag 54(1):1-14. doi:10.1016/j.jeem.2006.1012.1002

Myhre G, Fuglestvedt JS, Berntsen TK, Lund MT (2011) Mitigation of short-lived heating components may lead to unwanted long-term consequences. Atmos Environ 45: 6103-6106

Nardone A, Ronchi B, Lacetera N, Ranieri MS, Bernabucci U (2010) Effects of climate changes on animal production and sustainability of livestock systems. Livestock Sci 130(1-3):57-69. doi:10.1016/j.livsci.2010.02.011

Nolan BT, Hitt KL (2006) Vulnerability of shallow groundwater and drinking-water wells to nitrate in the United States. Environ Sci Technol 40:7834-7840

Peel J, Haeuber R, Garcia V, Neas L, Russell AG (submitted) Implications of nitrogen-climate interactions for ambient air pollution and human health. Biogeochemistry, special issue climate-nitrogen interactions (this issue)

Penner JE, Prather MJ, Isaksen ISA, Fuglestvedt JS, Klimont Z, Stevenson DS (2010) Short-lived uncertainty? Nat Geosci 3(9):587-588

Perkins TD, Adams GT, Lawson ST, Schaberg PG, McNulty SG (2000) Long-term nitrogen fertilization increases winter injury in montane red spruce foliage (Picea rubens) foliage. J Sustain For 10:165-177

Pinder RW, Davidson EA, Goodale CL, Greaver TR, Herrick JD, Liu L (2012) Climate change impacts of US reactive nitrogen. PNAS 109(20):7671-7675

Pinder R, Schlesinger W, Bonan G, Bettez N, Greaver T, Wieder W, Davidson EA (submitted) Impacts of human alteration of the nitrogen cycle in the US on radiative forcing. Biogeochemistry, special issue climate-nitrogen interactions (this issue)

Porter E, Bowman WD, Clark CM, Compton JE, Pardo LH, Soong J (submitted) Nitrogen, climate, and biodiversity. Biogeochemistry, special issue climate-nitrogen interactions (this issue)

Racherla PN, Adams PJ (2009) US ozone air quality under changing climate and anthropogenic emissions. Environ Sci Technol 43(3):571-577

Rao LE, Allen EB, Meixner T (2010) Risk-based determination of critical nitrogen deposition loads for fire spread in southern California deserts. Ecol Appl 20: 1320-1335

Reid CE, O'Neill MS, Gronlund CJ, Brines SJ, Brown DG, Diez-Roux AV, Schwartz J (2009) Mapping community determinants of heat vulnerability. Environ Health Perspect 117:1730-1736

Robertson GP, Vitousek PM (2009) Nitrogen in agriculture: balancing the cost of an essential resource. Ann Rev Environ Resour 34:97-125

Roberston GP, Bruulsema TW, Gehl R, Kanter D, Mauzerall D, Rotz A, Williams C (submitted) Climate-nitrogen interactions in agriculture. Biogeochemistry, special issue climate-nitrogen interactions (this issue)

Rotz CA (2004) Management to reduce nitrogen losses in animal production. J Anim Sci (Suppl) 82:E119-E137 
Rusznak C, Devalia JL, Davies RJ (1996) Airway response of asthmatic subjects to inhaled allergen after exposure to pollutants. Thorax 51:1105-1108

Rypdal K, Rive N, Berntsen T, Fagerli H, Klimont Z, Mideksa TK, Fuglestvedt JS (2009) Climate and air quality-driven scenarios of ozone and aerosol precursor abatement. Environ Sci Policy 12:855-869

SAB (Science Advisory Board to the EPA) (2011) Reactive nitrogen in the United States; an analysis of inputs, flows, consequences, and management options. US EPA, Washington, DC

Seitzinger S, Harrison JA, Bohlke JK, Bouwman AF, Lowrance R, Peterson B, Tobias C, Van Drecht G (2006) Denitrification across landscapes and waterscapes: a synthesis. Ecol Appl 16(6):2064-2090. doi:10.1890/1051-0761(2006)016 [2064:dalawa]2.0.co;2

Stelson AW, Seinfeld JH (1982) Relative-humidity and temperature-dependence of the ammonium-nitrate dissociation-constant. Atmos Environ 16:983-992

St-Pierre NR, Cobanov B, Schnitkey G (2003) Economic losses from heat stress by US livestock industries. J Dairy Sci (Suppl) 86(Supplement 1):E52-E77

Sylvan JB, Dortch Q, Nelson DM, Brown AFM, Morrison W, Ammerman JW (2006) Phosphorus limits phytoplankton growth on the Louisiana shelf during the period of hypoxia formation. Environ Sci Technol 40(24):7548-7553. doi: 10.1021/es061417t

Thomas RQ, Canham CD, Weathers KC, Goodale CL (2010) Increased tree carbon storage in response to nitrogen deposition in the US. Nat Geosci 3:13-17

Townsend AR, Howarth, RW (2010) Fixing the global nitrogen problem. Sci Am Mag 32-39

Townsend AR, PM Vitousek PM, BZ Houlton BZ (2012) The climate benefits of better nitrogen and phosphorus management. Issues Sci Technol 28(2):85-91

US-EPA (U.S. Environmental Protection Agency) (2006) Air quality criteria for ozone and related photochemical oxidants. EPA/600/R-05/004aF-cF. U.S. Environmental Protection Agency, Washington
US-EPA (U.S. Environmental Protection Agency) (2008) Integrated science assessment (ISA) for oxides of nitrogen and sulfur-ecological criteria (final report) (ISA). Office of Research and Development, National Center for Environmental Assessment, EPA/600/R-08/082 Research, Triangle Park

US-EPA (U.S. Environmental Protection Agency) (2009) Integrated science assessment for particulate matter (final report). EPA-600-R-08-139F. RTP Division, National Center for Environmental Assessment. http://cfpub.epa. gov/ncea/cfm/recordisplay.cfm?deid=216546

US-EPA (U.S. Environmental Protection Agency) (2011) Inventory of U.S. greenhouse gas emissions and sinks: 1990-2009. Report EPA 430-R-11-005. Washington, DC, USA

Vitousek PM, Aber JD, Howarth RW, Likens GE, Matson PA, Schindler DW, Schlesinger WH, Tilman DG (1997) Human alteration of the global nitrogen cycle: sources and consequences. Ecol Appl 7(3):737-751

Ward MH, deKok TM, Levallois P, Brender J, Gulis G, Nolan BT, VanDerslice J (2005) Workgroup report: drinkingwater nitrate and health-recent findings and research needs. Environ Health Perspect 113(11):1607-1614. doi:10.1289/ ehp. 8043

Weaver C, Liang XZ, Zhu J, Adams P, Amar P, Avise J, Caughey M, Chen J, Cohen R, Cooter E et al (2009) A preliminary synthesis of modeled climate change impacts on U.S. regional ozone concentrations. Bull Am Meteorol Soc 90(12):1843-1863. doi:10.1175/2009bams2568.1

Wu S, Mickley LJ, Leibensperger EM, Jacob DJ, Rind D, Streets DG (2008) Effects of 2000-2050 global change on ozone air quality in the United States. J Geophys Res. 113(D6): D06302. doi:10.1029/2007jd008917

Zavaleta ES, Shaw MR, Chiariello NR, Mooney HA, Field CB (2003) Additive effects of simulated climate changes, elevated $\mathrm{CO}_{2}$, and nitrogen deposition on grassland diversity. Proc Nat Acad Sci 100(13):7650-7654 